\author{
®А. В. Бойчук ${ }^{2}$, В. І. Бойко ${ }^{1}$, I. М. Нікітіна ${ }^{1}$, Б. М. Бегош ${ }^{2}$ \\ 'Сумський державний університет \\ ${ }^{2}$ ДВНЗ « Тернопільський державний медичний університет імені I. Я. Горбачевського \\ МO3 України»

\section{УЛЬТРАЗВУКОВІ КРИТЕРІЇ СТАНУ ШИЙКИ МАТКИ В ДІАГНОСТИЦІ ЗАГРОЗИ ПЕРЕДЧАСНИХ ПОЛОГІВ ПРИ БАГАТОПЛІДНІЙ ВАГІТНОСТІ}

УЛЬТРАЗВУКОВІ КРИТЕРІЇ СТАНУ ШИЙКИ МАТКИ В ДІАГНОСТИЦІ ЗАГРОЗИ ПЕРЕДЧАСНИХ ПОЛОГІВ ПРИ БАГАТОПЛІДНІЙ ВАГІТНОСТІ. Вивчена динаміка стану шийки матки при багатоплідній та одноплідній вагітності 3 використанням трансвагінальної ехографії. Виявлена відмінна особливість стану шийки матки при двійні, що полягає у більш швидкому скороченні шийки після 24 тижнів порівняно з одноплідною вагітністю. Розроблені ультразвукові критерії довжини шийки матки для своєчасного формування групи підвищеного ризику передчасних пологів серед пацієнток із двійнею. Розроблені нормативи довжини шийки матки для кожного гестаційного терміну при двійні. Встановлені «критичні» терміни (22-24 тижні), коли необхідно проводити дослідження шийки матки для визначення ступеня ризику передчасних пологів. При довжині шийки матки <34 мм в 22-24 тижні підвищений ризик передчасних пологів; критерієм ризику передчасних пологів в $32-35$ тижні $€$ довжина шийки матки <27 мм, критерієм ризику «ранніх» передчасних пологів (до 32 тижнів) - <19 мм.

УЛЬТРАЗВУКОВЫЕ КРИТЕРИИ СОСТОЯНИЯ ШЕЙКИ МАТКИ В ДИАГНОСТИКЕ УГРОЗЫ ПРЕЖДЕВРЕМЕННЫХ РОДОВ ПРИ МНОГОПЛОДНОЙ БЕРЕМЕННОСТИ. ИзУчена динамика состояния шейки матки при многоплодной и одноплодной беременности с использованием трансвагинальной эхографии. Обнаружена отличительная особенность состояния шейки матки при двойне, заключающаяся в более быстром сокращении шейки после 24 недель по сравнению с одноплодной беременностью. Разработаны ультразвуковые критерии длины шейки матки для своевременного формирования группы повышенного риска преждевременных родов среди пациенток с двойней. Разработаны нормативы длины шейки матки для каждого гестационного срока при двойне. Установлены «критические» сроки (22-24 недели), когда необходимо проводить исследование шейки матки для определения степени риска преждевременных родов. При длине шейки матки <34 мм в 22-24 недели повышенный риск преждевременных родов; критерием риска преждевременных родов в $32-35$ недель является длина шейки матки <27 мм, критерием риска «ранних» преждевременных родов (до 32 недель) - <19 мм.

ULTRASOUND CRITERIA OF THE CERVIX UTERI IN THE DIAGNOSIS OF PRETERM CHILDBEARING IN MULTIPLE PREGNANCY. The dynamics of the state of the cervix in multiple and singleton pregnancy using transvaginal sonography was studied. Distinctive feature state of the cervix with twins, that is more rapid reduction of cervical after 24 weeks compared with singleton pregnancy was revealed. Ultrasound cervical length criteria for early formation of an increased risk of preterm delivery among patients with twins was developed. Standards cervical length for each gestational period in twins was developed. "Critical» periods (22-24 weeks) when it is necessary to conduct research cervix to determine the degree of risk of preterm birth was installed. With a length of cervix $<34 \mathrm{~mm}$ in 22-24 weeks increased risk of preterm birth; of the risk of preterm birth at $32-35$ weeks is cervical length $<27 \mathrm{~mm}$, the criterion of risk «early» preterm birth (before 32 weeks) - <19 mm.

Ключові слова: багатоплідна вагітність, невиношування вагітності, загроза передчасних пологів, трансвагінальна ультрасонографія.

Ключевые слова: многоплодная беременность, невынашивание беременности, угроза преждевременных родов, трансвагинальная ультрасонография.

Key words: multiple pregnancy, miscarriage, threat of premature birth, transvaginal ultrasonography.

ВСТУП. За останні роки вагітність і пологи при багатоплідді постали однією з найактуальніших проблем сучасного акушерства [1]. Це зумовлено широким впровадженням у практику охорони здоров'я ефективних методик лікування неплідності різного генезу, у тому числі й засобами сучасних репродуктивних технологій, що дозволило істотно підвищити ефективність лікування порушень репродуктивної функції в подружніх пар [2]. Лише за період з 2000 по 2014 рр. в Україні відбулося зростання частоти багатоплідних пологів більш ніж на 30 \%. Разом 3 тим виникли і нові наукові питання стосовно особливостей клінічного перебігу гестаційного періоду у жінок з багатоплідною вагітністю. В переліку виникаючих завдань особливе місце належить питанню невиношування вагітності у жінок даної групи. У більшості випадків самовільне припинення вагітності має повторюваний характер, що свідчить про наявність постійно присутніх факторів, які обумовлюють такий розвиток подій [4]. Частота передчасних пологів при багатоплідді становить 54,3 \% порівняно з 9,7\% при одноплідній вагітності $[3,4]$. Втрачені вагітності становлять майже $17 \%$ усіх бажаних вагітностей, при цьому $75-80$ \% викиднів трапляються у ранніх термінах (до 12 тижнів вагітності), і, на жаль, немає тенденції до зниження цих показників [8]. 


\section{Акушерство та гінекологія}

БЛИЗЬКО ПОЛОВИНИ вагітностей двійнею і до 80 \% трійнею перериваються до 36 тижнів. За даними J. Lumley (1993), у Європі 17 \% багатоплідних вагітностей перериваються В 20-27 ТИЖНІВ, 21 \% - між 28 і 31 тижнем і 17 \% ПОЛОПВ відбуваються між 32 і 36 тижнем. Серед ПОЛОПВ, ЩО відбулися до 32 тижнів, 25 \% становлять багатоплідні ПОЛОГИ. У зв'язку 3 вищевказаним, максимальне пролонгування багатоплідної вагітності $€$ важливою умовою зниження перинатальної захворюваності і смертності у даної групи пацієнток ВИСОКОГО ризику.

Для своєчасного формування групи підвищеного ризику передчасних пологів серед пацієнток 3 багатопліддям багатьма вченими проводиться пошук прогностичних критеріїв загрози передчасних ПОЛОГВ як при одноплідній, так і при багатоплідній вагітності. Трансвагінальний моніторинг при багатоплідді несе цінну інформацію про стан шийки матки (довжина, внутрішній зів, цервікальний канал) і сприяє своєчасному формуванню групи підвищеного ризику передчасних пологів. Впровадження трансвагінального ультразвукового дослідження для ОЦНКИИ ШИЙКИ матки під час вагітності вперше запропонували J. Brown і співавт. у 1986 році. На даний час трансвагінальна ехографія $€$ практично безальтернативним методом дослідження, ЩО використовується для характеристики шийки матки і дозволяє оцінити істинну довжину шийки матки на всьому протязі, а також стан внутрішнього зіва, маючи суттєві переваги перед пальцевим дослідженням шийки матки і трансабдомінальною ехографією. Отже, застосування трансвагінального ультразвукового дослідження для ОЦНКИ ШИЙКИ матки під час вагітності $\epsilon$ надійним прогностичним критерієм у комплексній діагностиці загрози передчасних пологів при багатоплідді. Широке впровадження цього методу діагностики у повсякденну практику антенатального догляду ДОЗВОЛИТЬ суттєво покращити перинатальні показники.

Мета дослідження - ВИВЧИТИ особливості динаміки стану шийки матки В міру прогресування вагітності і виявлення ультразвукових критеріїв ризику передчасних пологів у пацієнток із двійнею.

МАТЕРІАЛИ ТА МЕТОДИ. Для вирішення поставлених у роботі задач було проведено проспективний аналіз 150 історій хвороб жінок 3 одноплідною вагітністю та 200 історій хвороб вагітних 3 двійнею (114-3 дихоріальною, 86 - 3 монохоріальною діамНОТИЧНОЮ), ЩО перебували на обліку В жіночій консультації та лікуванні В Сумському обласному клінічному перинатальному центрі В 2011-2014 рр. Для розробки ультразвукових критеріїв стану шийки матки нами були виділені такі групи. Контрольну групу склали 100 пацієнток, у яких вагітність перебігала без ЯВИЩ загрози переривання, і ПОЛОГИ у яких відбулися В терміні доношеної вагітності (50 - 3 ОДНОППДНОЮ вагітністю, 50 - 3 багатопліддям). В основну групу було включено 100 пацієнток 3 одноплідною вагітністю (група 1) і 1503 двійнею (група 2), у яких перебіг вагітності був ускладнений загрозою переривання у різні терміни гестації. Усі пацієнтки, у яких вагітність була ускладнена загрозою переривання, отримували патогенетичну терапію згідно 3 діючими клінічними протоколами (наказ МО3 України № 624). У групу дослідження не були включені пацієнтки 3 істміко-цервікальною недостатністю і ЗВИЧНИМ НЄВИношуванням.

Нами було вивчено загальний, соматичний, акушерсько-гінекологічний анамнез, перебіг вагітності, пологів і зокрема стан шийки матки при прогресуванні одноплідної та багатоплідної вагітності. Крім клінічного обстеження і загальноприйнятих лабораторних досліджень, проводилася ультразвукова цервікометрія.

Для ОЦНКИ стану ФПК проводили УЗД плода і плацентарного комплексу за допомогою сучасного ультразвукового апарата «MEDISON» 3 використанням на ранніх термінах трансвагінального датчика 6,5 МГц, В більш пізні терміни КОНВеKCHИХ датчиків 3,5 і 5 МГц у двовимірному ехорежимі відповідно ДО термінів 1013 тиж., 16-22 тиж. та 28-34 тиж. вагітності. В І триместрі УЗ-діагностика здійснювалась із застосуванням двох стандартних методик: трансвагінальної ехографії, а також методики трансабдомінального сканування 3 наповненим сечовим міхуром. Для виконання трансвагінальної ехографії жінку зі звільненим сечовим міхуром клали у задню літотомну позицію. Ультразвуковий датчик ВВОДИЛИ у піхву, скеровуючи до переднього склепіння, при цьому намагаючись не тиснути на шийку, аби не спричинити їі штучного подовження. Після отримання сагітального розрізу шийки використовували ехогенну слизову ендоцервіксу для визначення внутрішнього вічка. Для вимірювання лінійної ДОВЖИНИ ШИЙКИ бігунці розміщували на трикутній ехогенній ділянці ЗОВНШШНЬОГО вічка та $\mathrm{V}$-подібній виїмці внутрішнього вічка. Кожне обстеження тривало близько 2 - 3 хвилин.

Статистичну обробку отриманих даних проводили параметричними методами 3 використанням комп'ютерних статистичних програм [4]. Статистичні дані цитовані 3 дисертаційної роботи Ірини Миколаївни Нікітіної «Затримка розвитку плода у вагітних, зайнятих у виробництві суперфосфату (прогнозування, профілактика та лікування)», захищеної у 2010 році. В дисертаційній роботі дані оброблялися 3 застосуванням варіаційно-статистичного методу аналізу отриманих результатів за допомогою персонального комп'ютера IBM PC Intel Celeron ${ }^{\mathrm{TM}} 556 \mathrm{MHz}$ та прикладної програми роботи 3 електронними таблицями Microsoft ${ }^{\circledR}$ Excel 97 В середовищі Windows Millenium. Статистичну обробку матеріалу проводили методами варіаційної та парної статистики, а також застосовували метод відмінності 3 використанням tкритерію Стьюдента. Отримані результати вважали вірогідними, ЯКЩО коефіцієнт достовірності р, який знаходили ПО таблиці Стьюдента, був меншим 0,05.

РЕЗУЛЬТАТИ ДОСЛІДЖЕННЯ ТАЇХ ОБГОВОРЕННЯ. Вік обстежуваних вагітних достовірно не відрізнявся і коливався від 18 до 39 років (В середньому становив $27,8 \pm 3,5$ року). При цьому у віці 30 років і більше було $33,0 \%$ пацієнток 1 групи та $32,7 \%$ вагітних 2 групи, В контрольній групі - 32,0 \% жінок. Екстрагенітальні захворювання відмічалися В обох групах спостереження у 61 \% пацієнток і були пред- 


\section{Акушерство та гінекологія}

ставлені: вегето-судинною дистонією, гіпертонічною хворобою різного ступеня тяжкості, хронічним пієлонефритом, рецидивуючою герпетичною інфекцією, невираженими формами ендокринопатій.

Гінекологічні захворювання в анамнезі (ерозія шийки матки, запальні захворювання придатків матки, синдром полікістозних яєчників, позаматкова вагітність, міома матки, пухлини і пухлиноподібні утворення яєчників) були виявлені у 44 пацієнток (44\%) з одноплідною вагітністю і у 72 пацієнток (48 \%) 3 багатоплідною вагітністю, в контрольній групі - 38 (38 \%) жінок. Стосовно безпліддя в анамнезі, то дане ускладнення частіше спостерігалося у пацієнток з двійнею (у пацієнток з багатоплідною вагітністю 54 випадки (36 \%) проти 21 випадку (21 \%) при одноплідній вагітності).

При аналізі перебігу вагітності, крім загрози переривання, у досліджуваних пацієнток були виявлені різні ускладнення: токсикоз першої половини, гестоз різного ступеня тяжкості, анемія, фетоплацентарна дисфункція, затримка росту плода/плодів, багатоводдя. Слід відзначити, що частота виявлених ускладнень була в 1,5-2 рази вища у пацієнток із двійнею. Виражене зниження рівня гемоглобіну (менше 100 г/л) відзначалося у 74 пацієнток 3 двійнею (49,3 \%), причому в половині спостережень анемія визначалася вже з I триместру вагітності. Гестоз ускладнив перебіг вагітності у 50 пацієнток 3 двійнею $(33,3 \%)$, що майже вдвічі вище частоти даного ускладнення при одноплідній вагітності. Це збігається 3 думкою більшості дослідників, які вказують нате, що частота прееклампсії при багатоплідді в 2-5 разів перевищує таку при одноплідній вагітності.

При ультразвуковому дослідженні в І триместрі вагітності визначався тип плацентації у вагітних з багатопліддям. Диференційний діагноз моно- і дихоріальної двійні в ранні терміни вагітності ґрунтувався на визначенні кількості плодових яєць, числа ембріонів у плодовому яйці, а також на виявленні Т- або Y- ознаки при ретельному дослідженні міжплодової перегородки. Товщина міжплодової перегородки, котра є одним з діагностичних критеріїв хоріальності, коливалась від 0,8 до 1,1 мм при монохоріальній двійні і від 1,4 до 2,8 мм при дихоріальному типу плацентації. У більш пізні терміни вагітності додатковими критеріями типу плацентації служили стать плодів, число плацент, а також відмінності в їх дозріванні (рис. 1).

Наші дослідження показали, що довжина шийки матки при ультразвуковому дослідженні в I триместрі вагітності становила в середньому $41,25 \pm 5,43$ мм. Не виявлено залежності довжини шийки в I триместрі вагітності ні від паритету, ні від наявності в анамнезі самовільних абортів і передчасних пологів.

У більшості пацієнток у 12-15 тижнів гестації при трансвагінальній ехографії цервікальний канал мав прямолінійну форму, у той час як у $15 \%$ вагітних він мав форму гачка.

В міру прогресування одноплідної вагітності довжина шийки матки достовірно не змінювалася до 25 тижнів, складаючи в 16-18 тижнів 40,02 $\pm 5,12$ мм, в

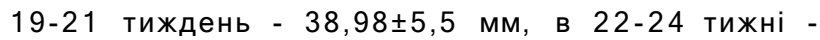
$38,6 \pm 4,9$ мм. При цьому відрізнялися і темпи укорочення шийки матки. Якщо в I половині вагітності швидкість укорочення довжини шийки матки становила 0,22-0,35 мм/тиж., то надалі вона прогресивно зростала. На початок III триместру вагітності (до 25 27 тижня) вона зростала до 0,58 мм/тиж., а після 36 тижнів досягала 1,02 мм/тиж.

Але вже до 22-24 тижня при багатоплідді зазначалися нижчі показники довжини шийки матки, ніж при одноплідній вагітності: $37,5 \pm 4,9$ мм проти $38,6 \pm$ 4,9 мм (відмінності статистично недостовірні). Тобто, як видно з таблиці 1 , починаючи з цього терміну, темпи укорочення шийки матки при вагітності двійнею значно перевищують такі при одноплідній вагітності. Так, у 25-27 тижнів довжина шийки матки при багатоплідді становила $33,2 \pm 4,5$ мм проти $36,85 \pm 5,0$ мм при одноплідній вагітності. При індивідуальному аналізі привертала увагу виражена варіабельність досліджуваного показника у пацієнток з багатопліддям: від 9,4 мм до 47,4 мм. Найбільш вираженою різниця в довжині шийки при багатоплідній і одноплідній вагітності відзначалася в III триместрі вагітності. Так, при багатоплідді, в 28-30 тижнів довжина шийки становила $30,25 \pm 4,1$ мм, в 31-33 тижні - 27,2 4,0 мм, в 34-36 тижнів - 21,8 $\pm 3,1$ мм. При одноплідній вагітності ці

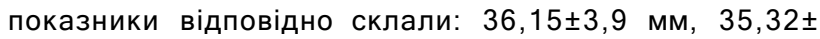
4,2 мм, 34,66 4,4 мм. До терміну пологів довжина шийки матки у пацієнток з багатопліддям становила $20,7 \pm 3,9$ мм проти $31,6 \pm 3,9$ мм при одноплідній вагітності. Такі відмінності в довжині шийки матки при ба-
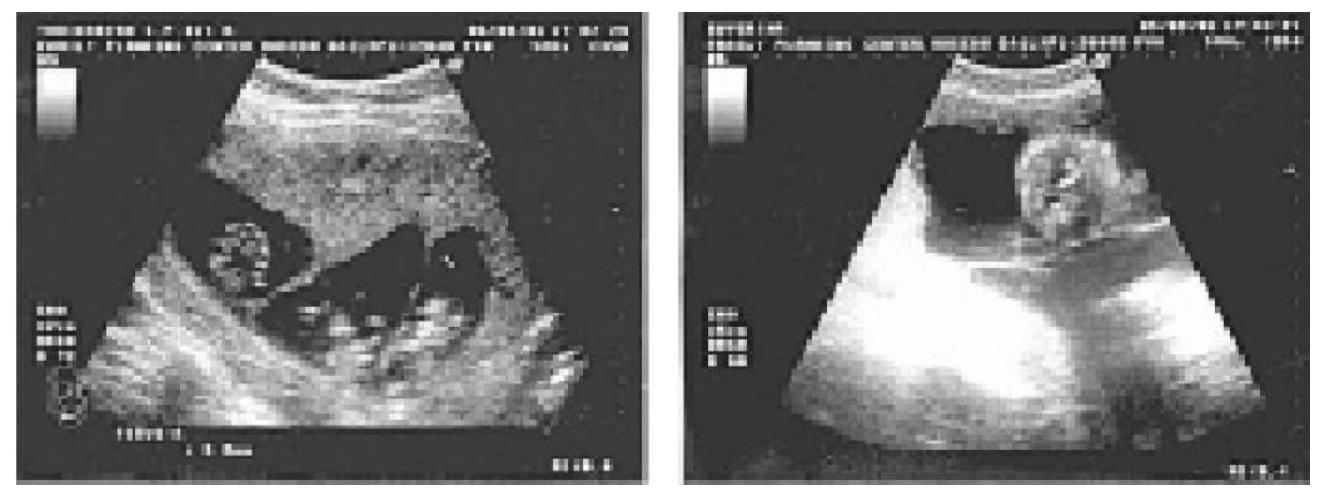

Рис. 1. Ультразвукові маркери хоріальності при багатоплідній вагітності. 


\section{Акушерство та гінекологія}

\section{Таблиця 1. Довжина шийки матки при ультразвуковому дослідженні}

\begin{tabular}{|c|c|c|}
\hline Термін вагітності & Одноплідна вагітність & Багатоплідна вагітність \\
\hline До 15 тижнів & $41,25 \pm 5,43 \mathrm{мm}$ & $41,25 \pm 5,43 \mathrm{мm}$ \\
\hline 16-18 тижнів & $40,02 \pm 5,12 \mathrm{Mм}$ & $40,02 \pm 5,12 \mathrm{Mm}$ \\
\hline 19-21 тиждень & $38,98 \pm 5,5 \mathrm{мm}$ & $38,98 \pm 5,5 \mathrm{~mm}$ \\
\hline 22-24 тижні & $38,6 \pm 4,9 \mathrm{mM}$ & $37,5 \pm 4,9 \mathrm{mM}$ \\
\hline 25-27 тижнів & $36,85 \pm 5,0 \mathrm{~mm}$ & $33,2 \pm 4,5 \mathrm{~mm}$ \\
\hline 28-30 тижнів & $36,15 \pm 3,9 \mathrm{~mm}$ & $30,25 \pm 4,1 \mathrm{~mm}$ \\
\hline 31-33 тижні & $35,32 \pm 4,2 \mathrm{MM}$ & $27,2 \pm 4,0 \mathrm{Mm}$ \\
\hline 34-36 тижнів & $34,66 \pm 4,4 \mathrm{Mm}$ & $21,8 \pm 3,1 \mathrm{MM}$ \\
\hline
\end{tabular}

гатоплідній і одноплідній вагітності пояснюються різними темпами ї̈ скорочення.

Аналіз перинатальних наслідків проводився з урахуванням термінів і методу розродження. Передчасні пологи при одноплідній вагітності мали місце у 33 пацієнток (33 \%). При багатоплідній вагітності передчасні пологи настали у 45 пацієнток $(66,2 \%)$ з монохоріальною двійнею, при дихоріальній двійні відсоток передчасних пологів був меншим і склав, відповідно, 35 (42,7 \%). 370 пацієнток з багатоплідною вагітністю (основна група 2), що народили в строк, незважаючи на загрозу переривання, у 51 стан шийки матки (довжина, внутрішній зів, цервікальний канал) достовірно не відрізнявся від такого у пацієнток з контрольної групи. У 9 (6 \%) пацієнток з двійнею, які народили своєчасно, довжина шийки матки була достовірно нижче норми на всіх термінах гестації, однак проведена терапія загрози переривання в умовах стаціонару $з$ дотриманням суворого ліжкового режиму, токолізу до 36 тижнів сприяла сприятливому результату пологів - народженню доношених дітей.

Подальше обговорення результатів дослідження буде стосуватися тільки 80 пацієнток з багатоплідною вагітністю, ускладненою загрозою переривання, які народили передчасно. Нами проведено індивідуальний аналіз значень довжини шийки матки у пацієнток, які народили передчасно, залежно від термінів розвитку спонтанної пологової діяльності (пологи в 32-35 тижнів - 59 пацієнток (39,3\%), і до 32 тижнів - 21 (14,0 \%) пацієнток).

При аналізі результатів дослідження довжини шийки матки за даними трансвагінальної ехографії у пацієнток з двійнею, які народили передчасно, до 19-21 тижня довжина шийки матки була практично ідентична такій у контрольній групі. Так, довжина шийки матки початково до 15 тижнів становила

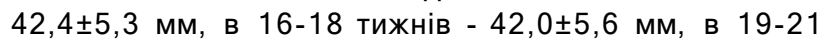
тиждень - 38,0 $\pm 4,9$ мм, а у вагітних з багатопліддям

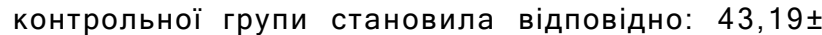

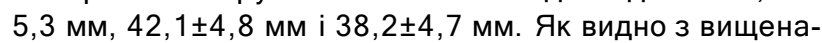
ведених даних, у пацієнток з багатопліддям, які народили передчасно, найбільші відмінності в темпах укорочення довжини шийки матки, порівняно з тими, що народили в строк, відзначалися в 20-23 тижні, коли швидкість щотижневого укорочення шийки матки в 6,8 раза перевищувала таку у пацієнток, які народили в строк (1,57 мм/тиж. проти 0,23 мм/тиж.). Подібна тенденція динаміки довжини шийки матки зберігалася протягом всієї вагітності.
При індивідуальному аналізі значень довжини шийки у пацієнток з двійнею, які народили передчасно, нами виявлена чітка кореляція динаміки зміни шийки матки в ці терміни з терміном розвитку спонтанної пологової діяльності. До 22-24 тижнів гестації динаміка змін з боку шийки матки була практично ідентичною. Однак, починаючи з цього терміну (22-24 тижні), у пацієнток, які народили до 32 тижнів, швидкість укорочення шийки матки була більше вираженою: 5,53 мм/тиж. проти 2,33 мм/тиж. у пацієнток, які народили в 32-35 тижнів. В терміні пологів у 32-35 тижнів довжина шийки матки становила 28ะ3,8 мм в 25-27 тижнів, а при передчасних пологах до 32 тижнів шийка матки була в 1,47

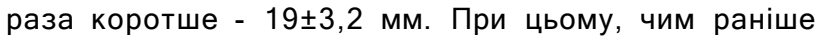
наступали пологи при двійні, тим більш значущими були зміни з боку шийки матки, які проявлялися не тільки її укороченням, але i V- або U-подібним відкриттям внутрішнього зіва. У пацієнток з багатопліддям, які народили передчасно, як і у пацієнток, які народили в строк, ми не виявили достовірних відмінностей в довжині шийки матки у повторно- i першороділей, а також залежності від типу плацентації (моно- і дихоріальна двійня). Виняток склали 3 (2 \%) пацієнтки 3 монохоріальними двійнями 3 різким укороченням шийки матки (до 13-15 мм) в 25-27 тижнів, що обумовлено не типом плацентації, а наявністю вираженого багатоводдя в одного 3 плодів при синдромі фето-фетальної трансфузії важкого ступеня, який ускладнює до 15 \% монохоріальних двієнь.

Враховуючи високу частоту передчасного переривання вагітності при двійні, необхідний ретельний трансвагінальний ультразвуковий моніторинг шийки матки. Ультразвуковими критеріями ризику передчасних пологів $€$ вкорочення шийки матки, розширення внутрішнього зіва і цервікального каналу. Оптимальними термінами для своєчасного виявлення пацієнток високого ризику щодо передчасних пологів при двійні $€$ 22-24 тижні гестації. У пацієнток з двійнею довжина шийки матки <34 мм у 22-24 тижні вказує на підвищений ризик передчасних пологів; критерієм ризику передчасних пологів у 32-35 тижнів є довжина шийки матки <27 мм, а критерієм ризику «ранніх» передчасних пологів (до 32 тижнів) - <19 мм.

ВИСНОВОК. Доведено, що високоефективним методом прогнозування передчасних пологів $\epsilon$ трансвагінальна ехографія, яка дозволяє здійснити оцінку довжини шийки матки, стан внутрішнього зіва та цервікального каналу протягом вагітності. 


\section{Акушерство та гінекологія}

Визначено, що довжина шийки матки прогресивно зменшується протягом багатоплідної та одноплідної вагітності з фізіологічним перебігом: з 43,9 5 , 3 мм до $20,7 \pm 3,9$ мм і з $41,25 \pm 5,4$ мм до $31,6 \pm 3,9$ мм відповідно. Доведено, що відмінною ознакою стану шийки матки при багатоплідній вагітності є ї̈ більш швидке вкорочення після 24 тижнів порівняно з одноплідною; швидкість укорочення в ці терміни, відповідно, становить 1,43 мм/тиж. проти 0,58 мм/тиж.

Встановлено ультразвукові критерії ризику передчасних пологів при багатоплідній вагітності - це довжина шийки матки в 22-24 тижні <34 мм; критерій ризику передчасних пологів у 32-35 тижнів - довжина шийки матки <27 мм, а критерій ризику "ранніх» передчасних пологів (до 32 тижнів) - <19 мм. Науко- во доведено доцільність проведення у пацієнток із двійнею ультразвукового моніторингу шийки матки 3 визначенням її довжини і стану внутрішнього зіва, починаючи 322 тижнів вагітності.

ПЕРСПЕКТИВИ ПОДАЛЬШИХ ДОСЛІДЖЕНЬ. ПОглиблення вивчення проблем антенатального догляду при багатоплідній вагітності, впровадження обов'язкового ультразвукового дослідження в I триместрі вагітності з визначенням типу плацентації та включення трансвагінальної цервікометрії до обов'язкового алгоритму обстежень при багатоплідній вагітності. Широке впровадження цього методу діагностики у повсякденну практику антенатального догляду дозволить суттєво покращити перинатальні показники.

\section{СПИСОК ЛІТЕРАТУРИ}

1. Багатоплідна вагітність : навчальний посібник / під ред. Ю. П. Вдовиченко. - К., 2011. - 360 с.

2. Висаитова М. Б. Течение беременности и родов, перинатальные исходы при двойне : автореф. дис. канд. мед. наук / М. Б. Висаитова. -М., 2003. - 106 с.

3. Герасимова А. А. Особенности динамики состояния шейки матки по мере прогрессирования беременности и выявление ультразвуковых критериев риска преждевременных родов у пациенток с двойней : автореф. дис. канд. мед. наук / А. А. Герасимова. - М., 2005. - 112 с.

4. Лапач С. Н. Статистические методы в медикобиологических исследованиях с использованием Exel / С. Н. Лапач, А. В. Чубенко, П. Н. Бабич. - К. : Морион, 2000. - 320 с.

5. Калашников С. А. Оценка физического развития новорожденных из двойни / С. А. Калашников,
Р. В. Зябликова, Л. Г. Сичинава // Вопр. гинекол., акуш. и перинатол. - 2004. - Т. 3, № 3. - С. 55-58.

6. Ультразвуковая фетометрия: справочные таблицы и номограммы / под ред. М.В.Медведева. 4-е изд. - М. : РАВУЗДПГ, Реальное Время, 2004.

7. Монохориальная двойня: особенности течения беременности и родов, перинатальные исходы / Л. Г. Сичинава, С. А. Калашников, О. Б. Панина [и др.] // Акуш. и гинекол. - 2003. - № 2. - С. 12-18.

8. Перинатальные исходы при многоплодной беременности / [Л. Г. Сичинава, О. Б. Панина, С. А. Калашников, А. С. Ермолаева] // Акуш. и гинекол. 2006. - № 4. - С.10-14.

9. Филиппова Н. А. Значение пренатальной эхографии в оценке характера роста плодов при многоплодной беременности : автореф. дис. канд. наук / Н. А. Филиппова. - Нижний Новгород, 2009. 